\title{
Discourses on educational support in the context of general upper secondary education
}

\section{Niemi, Anna-Maija}

2020-03-15

Niemi , A-M \& Laaksonen , L M 2020 , ' Discourses on educational support in the context of general upper secondary education ' , Disability \& Society , vol. 35 , no. 3 , pp. 460-478 . https://doi.org/10.1080/096

http://hdl.handle.net/10138/316279

https://doi.org/10.1080/09687599.2019.1634523

acceptedVersion

Downloaded from Helda, University of Helsinki institutional repository.

This is an electronic reprint of the original article.

This reprint may differ from the original in pagination and typographic detail.

Please cite the original version. 
This manuscript will be published in Disability \& Society.

\section{Niemi, Anna-Maija \& Laaksonen, Linda Maria \\ Discourses on educational support in the context of general upper secondary education}

\section{Introduction}

The Finnish education system is characterized by nine years of comprehensive, high-quality education for all children and young people. In addition, guaranteeing reasonable educational opportunities after basic education is an important societal objective. After basic education, upper secondary education divides sharply into separate types of schools - general and vocational - which differs from other Nordic and many other European school systems (Nylund et al. 2018; Eurydike 2018). ${ }^{1}$ Young people in Finland must basically choose between those two options. About 95 per cent of students continue into upper secondary education; of these, 53 per cent choose general education and 42 per cent choose vocational schools (OSF 2017). ${ }^{2}$ General upper secondary education is described as providing students with extensive general knowledge, the principle objective being to enable further studies in higher education (MINEDU 2018). Vocational education primarily prepares students for working life. Vocational schools have long traditions in educating young people who have different needs in terms of support, and support practices such as special education have been established in vocational schools (Niemi 2015). In contrast, general upper secondary schools are considered to serve more 'academically orientated' students. These schools have traditionally not had established support practices, as before 2019, Finland's general upper secondary education act did not require the provision of special education.

In this article, we examine the practices of educational support as well as the meanings that general upper secondary school practices give support and the need for support. We are interested in both the discourses that define and construct the meaning-making and the practices in everyday school life, which formulate the definitions of support. The article is based on an ethnographic study of educational support, study counselling and societal

\footnotetext{
${ }^{2}$ In Finland, most young people who do not continue to upper secondary schools enter preparatory training programmes for vocational schools or general upper secondary schools (OSF 2018).
} 
This manuscript will be published in Disablity \& Society.

inclusion of young people in upper secondary education in the Helsinki metropolitan area. We analyse the data produced in one general upper secondary school during the school year 2016-17. Focusing closely on seven interviews of students and teachers and on fieldnotes on special education teachers' work, we pose the following questions: 1) How are the needs for support and the support practices discussed in the context of general upper secondary education? 2) What kinds of meanings do schools' everyday practices give support and the needs for support?

\section{Overview of Finnish general upper secondary school and educational support}

You have to create your own timetable and manage your own studies. It's a very challenging way to study for many students at that age. If you're a really straightforward and organized kind of person and learning feels effortless, then this kind of arrangement works great for you. Then it's nice to get to manage your own studies, but it's not easy for everyone.

Teacher, general upper secondary school

Previous studies show that students regarded as having special educational needs, as well as students with migrant backgrounds, are often guided into vocational studies rather than general upper secondary school (Kirjavainen et al. 2016; Jahnukainen et al. 2018). Steering towards vocational education has been justified because of a student's assumed deficiencies in academic learning and Finnish language skills (Niemi 2015). Even though, since the late 1990s, vocational diplomas have offered general eligibility to apply for higher education, the divide between vocational and general schools continues to influence educational choices in higher education (Haltia, Jauhiainen \& Isopahkala-Bouret 2017; Nylund et al. 2018). This relates to the history of general upper secondary school as an institution that prepares students for academic higher education. Students who are accepted to these schools have traditionally been seen as more academically orientated. The ideal of an academic student as able and not in need of any educational support persists and is reproduced in school practices and society in general (see also Langorgen \& Magnus 2018, 602). It is also related to definitions of disability and special educational needs which we understand as multifaceted, discursively produced phenomena tied to various societal, cultural, historical and material dimensions. We do not see disability or special educational needs as deriving from an individual's specific body functions, dis/abilities or other characteristics; we consider these to be constantly 
This manuscript will be published in Disablity \& Society.

produced, shaped and defined in relation to the norm of the ideal learner and within societal practices, such as education. (See e.g. Goodley 2014; Kauppila, Kinnari \& Niemi 2018.) In the general upper secondary school system in particular, different educational practices may disable students by hindering their participation, but also enable their participation by offering adequate support and possibilities for participation (see Mietola 2014).

As expressed by the teacher we interviewed and quoted above, for many students who are accepted to general upper secondary school, the studies are challenging - not least because of the course structure (which is not centred around a study group) and because organizing and managing one's studies requires self-responsibility. The supposed academic orientation of students is also the reason that special needs education has historically been mostly relegated to vocational schools, as it continues to be today. This practice is brought into question because many upper secondary school students have different kinds of needs for educational support related to learning, language skills or mental health. Because the previous act governing general upper secondary education did not provide for special education, the resources and practices devoted to educational support have varied from school to school, and decisions concerning its organization have been left to the municipalities and individual schools (General Upper Secondary Schools Act 1998; Mehtäläinen 2005; Sinkkonen et al. 2016). In recent years, however, political discussion on whether special education should be mandated by law for general upper secondary education has been lively, and the new law endorsed during the autumn of 2018 will come into force during 2019-2021. Even today not every general upper secondary school in Finland has full-time special education teachers, and fewer resources are directed towards the work of the few special education teachers in these schools than to special education teachers in vocational schools ${ }^{3}$. In this article we consider our research results in relation to the ongoing law reform and its potential outcomes.

\footnotetext{
${ }^{3}$ In vocational education, a student is entitled to special support in learning and studies if, because of a learning difficulty, disability, illness or another reason, they need long-term, regular support to achieve learning goals and a diploma. Special support means systematic, pedagogical support and special teaching and learning arrangements which are based on the student's goals and skills. (Vocational Education and Training Act 531/2017.) Nineteen per cent of students in vocational education for young people received special support in 2016, of whom 84 per cent studied in mainstream study groups, whereas the rest studied in special groups or vocational special education institutes (OSF 2018b).
} 
This manuscript will be published in Disablity \& Society.

The general upper secondary school curriculum consists of general knowledge subjects such as Finnish as a mother tongue, foreign languages and mathematics. The study of each subject is divided into separate courses. In addition to compulsory courses, students can choose other subjects to study, depending on their interests. The central structural element in Finnish general upper secondary education is the final test called the Matriculation Examination, which characterizes and concludes the three-year-long programme of study. Overall, the teachers focus on preparing students for this exam, because the test results affect the students' opportunities to apply for higher education. The ongoing reform of higher education student admission will further strengthen the role of the Matriculation Examination, as it will provide the option to apply for higher education on the basis of the matriculation certificate. ${ }^{4}$ If special arrangements appear to be necessary in order for a student to take the exam, a special education teacher can advise on how to request these arrangements from the Matriculation Examination board. This, however, seems to be the most time-consuming duty of a special education teacher's weekly workload, and as we will later show, the needs for support and the available support practices do not always meet in a school's everyday practices. In order to obtain special arrangements to take the exam, a student's reading and writing skills have to be officially tested by a special education teacher. After this, it is possible to request extra time, adjustments to parts of the exam, or for instance a private room in which to take the test.

\section{Discourses on support}

The focus of our theoretical consideration is the concept of support. We use it as an analytical category, meaning that we read the data by concentrating on the definitions and meanings given to support and the need for support expressed in the interview talk. We also examine the meanings of support and the need for support in a school's everyday practices. Drawing on earlier research in sociology as well disability and policy studies in education, we utilize two prevailing discourses, which define and formulate the concept of support and are used in schools' everyday life. These are rights and privilege discourse and the individual deficit and stigma discourse. In our analysis we show how school discussions and practices are positioned within these discourses by forming cross-cutting meanings and new kinds of knowledge formations.

\footnotetext{
${ }^{4}$ https://minedu.fi/en/faqs-about-student-admissions
} 
This manuscript will be published in Disablity \& Society.

The discourse on support seen as a right and a privilege is strongly attached to the education policy context. It is the core of inclusive education and the ethos for social justice in education. It holds that providing support for all students is part of establishing educational equality (UNESCO 1994). Within this discourse, special and sometimes also separate support practices are justified by the rights perspective, based on the argument that individual, targeted support forms the basis of educational equality (cf. Done \& Andrews 2018; Niemi \& Kurki 2014; Lalvani 2013; Arnesen et al. 2007; Florian et al. 2006). The main target of the current education policy, however, is to help and support students individually so that they can successfully manage their studies in mainstream educational contexts. Nevertheless, many students study in separate special education arrangements, although these routes special classes and schools - are invisible in the graphic representations of the Finnish educational system (Niemi 2017). This invisibility may be unintended, because special arrangements are considered a self-evident part of the system. Or it may be that the formal invisibility of special arrangements is clearly an attempt to strengthen the representation of the Finnish educational system as being in line with global ideals, that is, 'completely inclusive' and lacking any kind of separate support practices, even though these do exist (cf. Slee 2014). Previous research has shown that neo-liberal educational policies, which emphasize excellence and competitive aspects of schooling (Done \& Andrews 2018; Niemi \& Mietola 2017; Goodley 2014; Slee 2014) pose a major challenge to inclusive education. Because the focus of neo-liberal education policy is on the ideal student who is independent, entrepreneurial and competent, using this rationale means that inclusive schooling is only considered possible for students who are 'able enough' (see Kauppila, Kinnari \& Niemi 2018; Slee 2014). What is essential in the discourse on support seen as a right and a privilege is that special educational arrangements, support practices and diagnostics are seen as important and essential aspects of equalizing educational opportunities and therefore enhancing social justice (see Jahnukainen 2015), even though they may sometimes contribute to stigmatization.

The second discourse, on support seen as stigmatizing and attached to individual deficits, draws on sociological and disability research on medicalization and diagnostics, which often sees defining the needs for support as leading to stigmatizing practices and even to marginalization in school contexts (see e.g. Grue 2011; Benjamin 2002; Allan 1999). This discourse is entangled with long-standing discussions on special needs education being seen as separate from mainstream education. As Powell (2010, p. 4) stated, 'the process of 
This manuscript will be published in Disablity \& Society.

classification and the relevant categories persist, even when these are given new labels'. Here he refers to the contradictory process of investigating and naming students according to their assumed difficulties and disabilities in order to arrange their education. This also touches on the question of translating former disability-related terms into the politically correct language of different 'needs', where the term changes, but is ambiguous. Does it thus change the practice? (see e.g. Slee 2014; Youdell 2006). On the one hand, naming disabilities and special needs is seen as necessary and even essential in order to obtain resources for organizing support; on the other hand, such naming can be seen as stigmatizing students and separating them from one another (see also Grue 2011; Florian et al. 2006; Jauhiainen \& Kivirauma 1997). There is also the question of school culture: if diverse ways of learning and the need for support and support practices are not seen as part of a school's everyday life, such a view can contribute to stigmatization and create a divide between practices seen as normal and those seen as deviant. This contributes further to the student positions considered appropriate and ideal and those considered special and deviant (see Liasidou 2012; Youdell 2006; Ashby 2010).

\section{Data and analysis}

The analysis in the present article draws on the data produced during ethnographic fieldwork in one general upper secondary school in the Helsinki metropolitan area during the academic year 2016-17. Our data consist of observations on 40 school days and interviews with a total of 41 students and 7 teachers and study counsellors. We placed particular emphasis on following the work of special education teachers, which means that we observed the meetings and learning sessions that teachers held with individual students along with other meetings and negotiations. During the ethnographic fieldwork, our broad interest was in making sense of what happens in the school's everyday life and how people conceptualize both attending school and the educational practices in use. We see the ethnographic field as a manifold concept; the analysis stretches from particular institutions to education policy discourses, which form the wider context of the research (see e.g. Marcus 1995; Lahelma et al. 2014; Troman et al. 2006). Methodologically, the research interest is in practices, meaning-making and knowledge formation produced in the field. By attempting to get to know participants and building mutual trust, we drew on feminist ethnography, which places special emphasis on reflexivity, the recognition of power relations, and sensitivity to listening to research participants (Renold et al. 2008; Lahelma \& Gordon 2007; Skeggs 1995). These principles 
This manuscript will be published in Disablity \& Society.

have also guided our analysis and how we highlight research participants' interpretations of their experiences and viewpoints and point out the structures and practices framing their school attendance.

The data analysed systematically and more closely for this article consist of thematic interviews of teachers and special education teachers (4), school biographical interviews of students (3) who had participated in special needs education (see Niemi \& Mietola 2017, Henderson et al. 2007), and fieldnotes from various learning sessions, meetings and informal discussions with special education teachers. To contextualize the selected data, we reflect on them using additional student interviews produced during the fieldwork. The limited number of interviews allows accurate analysis and enables us to focus on the theme of the need for support and the discussions on theory and data. The teacher interviews concerned their current and previous work experiences, educational support and guidance, the development of their work, and students' educational paths and transitions. In the student interviews, we discussed the students' current life situation, studies, educational history, and future prospects.

We call our analysis dialogical thematization (Koski 2011). In principle, dialogical thematization means that qualitative research data are analysed in dialogue with theoretical concepts. The categories and themes that a researcher highlights in the data are reflected in the theoretical concepts the researcher has chosen. Our first reading focused on searching for selected data in order to map the sections and episodes in which educational support and/or needs for support are present. After this, we formed preliminary categories and summaries in which we aimed to describe what happened when the informants talked about support. The second reading focused on arranging the categories into themes. This phase used theoretical concepts: we intended to create a constant dialogue between theory and data during the analysis by leaning on the research literature while also giving the data a voice. We also used elements of discourse analysis so that the emphasis in the reading was on the ways in which certain discourses set limits to what could be said (see Bacchi 2000) and considered relevant knowledge in a particular school context. However, we do not see the discourses of education as totalising; we rather see them as multiple and contradictory, and we see analysis as searching for ways in which meanings and everyday practices are constructed and maintained in education. 
This manuscript will be published in Disablity \& Society.

In the next two analytical sections and in the concluding section, we present and elaborate our findings as we answer our research questions: 1) How are the needs for support and support practices discussed in the context of general upper secondary education? 2) What meanings are given to support and the need for support?

\section{Support as a right and a privilege: Individual or a mainstream classroom practice?}

Through the analysis of special education teachers' narrations, it became evident that the Finnish Matriculation Examination board clearly defines the tasks of special education teachers. In order to obtain support (i.e. special arrangements) for the Matriculation Examination, the teachers are obliged to give a statement to the board concerning a student's reading and writing difficulties. This means that a huge amount of a special education teacher's weekly workload is devoted to testing students and writing statements accordingly. In line with the right and privilege discourse, this work has to be prioritized over other work responsibilities. Consequently, these tasks mean that support resources are used widely for testing - and are taken from resources that could be used for other pedagogical purposes and support practices. The teachers argued for more communal and collaborative pedagogical practices, but at the same time, they stated that there was no time to organize co-teaching with subject teachers in the classrooms. The paradox is that the teachers seemed to recognize the need to do their work 'differently', yet felt that they had insufficient time to make any changes:

I feel that if I just ask them [the students] to come by my office, they'll come but nothing big happens there, ever. It'll only scratch the surface: 'a special ed teacher helped me a bit, but does it really help? When I'm working in the classrooms, it's perhaps more efficient, and then like, then I'm with them, and if I could be there all the time, then it would be far more efficient.

(Special education teacher)

One special education teacher we interviewed argued that when she is involved in ordinary classroom work, she feels she can bring support practices closer to the students and they also get to know her better. In addition, she raised the viewpoint of efficacy, saying that when she is in the classroom as a co-teacher, she can implement pedagogical support practices because the students are already at work and doing their tasks. The teacher justified her view by saying that in meeting students individually in a separate classroom, one can only give a 
This manuscript will be published in Disablity \& Society.

small amount of the support that could be given in an ordinary classroom; meeting a student individually, she observed, always requires time to get to know the student and listen to their ideas. Not until a student and a teacher have become acquainted do the needs for support arise. This argument strongly leans on the principles of inclusive education, which hold that students should primarily be supported in their mainstream educational contexts - not in separate 'special' environments - to avoid stigmatization and to enhance participation and belonging (see Niemi \& Mietola 2017; Lalvani 2013; UNESCO 1994). Our analysis indicates that because the resources for special education in general upper secondary schools are scarce, the support practices focus on separate, individual learning sessions and testing: a teacher generally meets a student individually, tests the student's reading and writing skills, and composes a statement accordingly. This practice is positioned in contrast to the flexible, general and inclusive support practices offered to all learners in mainstream classrooms, using methods of co-teaching, for instance, which is in fact a pedagogical practice that the curriculum requires schools to develop.

Well yes, it's almost always the tests that need to be done - co-teaching in classes is something you unfortunately need to drop first when you don't have the time. Individual support has to be given first, collective aid comes afterwards.

(Special education teacher)

From the perspective of educational equality, it seems important that it is the legal responsibility of special education teachers to test students and write statements as part of their work. Current practice stands for equal availability of educational support, which should be every student's right; yet special education teachers are employed and two subject teachers are required to write the statement concerning a student's learning difficulties. According to the teachers we interviewed, this arrangement supports students' legal protection and has been a desirable development, replacing the former practice whereby it was the student's responsibility to consult a medical doctor to obtain a statement of learning difficulty. The former practice was seen as unfair, because the student and their family had to pay the doctor's expenses. Instead of being seen as enhancing educational equality, this practice was seen as exclusive. We argue that the viewpoint of a student's legal protection is formed within the right and privilege discourse and shapes support as consultative aid because special education teachers do not teach the subjects for which they are not qualified. This challenges the arguments presented above for providing flexible, general support in the 
This manuscript will be published in Disablity \& Society.

classrooms to all students in need of it. Due to insufficient resources, the role of individual support has been emphasized in the provision of support. As our analysis shows, individual support seemed to have positive impacts on students' study skills and interest in learning, but at the same time, differentiated and marginalized the role of pedagogical support in schools. As we further show, it may also marginalize the students' positions.

\section{Self-responsibility and stigmatization in seeking support: The special education teacher as remote consultant}

Among the other cross-cutting objectives of the general upper secondary school's national curriculum, self-responsibility and individual goal-setting are strongly emphasized as skills that students have to develop during their studies (FNAE 2015). In line with these objectives, our analysis of student interviews indicates that, to receive support at school, a student has to be active and take responsibility for making contact with the teachers. One student we interviewed describes in the extract below how she took the initiative to talk to a study counsellor about her difficulties:

I myself started to think about that what was going on with my grades. Why had they dropped so much? And I went to talk to the study counsellor. I [laughs] tried to fix the situation somehow. Like that.

(Female student, $1^{\text {st }}$ grade)

Her pro-active approach led to a concrete solution in which a study counsellor organized a multi-professional meeting with the student and her parents. As a result of the meeting, the student got to know the school's special education teacher; they met several times and practised various study and learning techniques. In the interview, the student reflected on the meetings, saying that 'it hasn't harmed me in any way that, of course, I got good tips from her about how to do my homework and how it would be good to study'. In analysing her interview, we recognized no negative associations with special needs education; in line with the right and privilege discourse, she seemed to consider the meetings as educational services to which she was entitled. However, this was not the case with all the students. Some of them argued that teachers should be more active in offering them support:

Usually if you want to get support, you have to go and ask yourself. In my opinion, the teachers should be more active. Sometimes I'm like I don't want to ask for help 'cause it's embarrassing, because if I go and ask for help, how do I do this? I don't wanna do that. Then I feel bad and I'm just like, damn! I can't 
This manuscript will be published in Disablity \& Society.

do this. And then the teacher thinks he's a stupid kid because he can't do this, even though I told him how to do it. Then you just think like, yeah, so do I want to go and talk to the teacher and say that I haven't learned these things?

(Male student, $2^{\text {nd }}$ grade)

For some of the students, asking for help and getting individual support from the special education teacher was not so straightforward. It may have reminded them of their comprehensive school special education classes, their marginalized position at school or possible experiences of being bullied because of the label of a 'special needs student' or being regarded as a non-ideal skilful learner (see Niemi \& Kurki 2014; Youdell 2006; Benjamin 2002). Some of the teachers also supported this interpretation of the negative label of special education, but interestingly, they explained the phenomenon from different angles:

We come back to the theme of whether having private meetings with the special education teacher is stigmatizing for students. One special education teacher talked about a boy who said to her when she entered a classroom, 'Please, leave! We don't have any problems here, but it seems that you have some'.

(Fieldnotes, meeting with a special education teacher)

This argument highlights how a special needs statement and support practices offered by a teacher known as a 'special education teacher' can stigmatize students. To avoid such a stigma, support should be offered individually and privately, with only one student and one teacher meeting at a time. The argument is positioned opposite the objective of inclusive education, because it holds that bringing pedagogical support into the classrooms can actually emphasize the stigma. Moreover, the student we interviewed pointed out the additional inconvenience of asking for help and confessing the need for support in front of both the teacher and their schoolmates. He argued that teachers should be more aware of the educational needs of students: 'they could draw on what is said in each student's papers' to offer support and take into account diverse learners in their teaching. (see e.g. Mietola 2014; Benjamin 2002; Allan 1999.) The teachers commonly believed that offering flexible and general support was important in reducing the stigmatization associated with both special education and support directed clearly (and only) towards those students who, as learners, are positioned outside the norm of the ideal student. The school curriculum also emphasized that support practices should primarily be organized among mainstream classes by shaping pedagogical practices, and separate arrangements should be avoided. It seems, however, that 
This manuscript will be published in Disablity \& Society.

school-related support needs are not yet part of the academic upper secondary school culture, and this appears to contribute to the marginal position of special needs education and diverse support practices.

Both teachers and students emphasized the importance of testing as early as possible so that a special education teacher can get to know the students and the students can be supported accordingly during their upper secondary studies. Moreover, the teachers raised an important, yet critical issue concerning the course-based structure of general upper secondary studies, namely that subject teachers do not see individual students often enough to be aware of their needs for support. The teachers argued that the number of students in each classroom and the time pressure in their daily work also affect a teacher's opportunities to identify and recognize students' support needs. This was mentioned particularly by those teachers who, in addition to subject teaching, were responsible for a study group. One of the group leader's work tasks is to identify educational support needs and, if necessary, guide students towards meeting special education teachers. Parents and young people were seen as having the freedom of choice whether or not to seek support; meetings with a special education teacher were also arranged according to students' wishes and willingness to seek support. We interpret this argument as being attached to the self-responsibility discourse according to which a school's educational culture offering and obtaining educational support is strongly related to the wishes and activeness of the students and their parents as well as to their sense of responsibility (see also Niemi \& Jahnukainen 2018; Kosunen 2016; Tomlinson 2008). Nevertheless, teachers considered it critical, arguing that the students who actively seek support are those who already cope well at school. On the other hand, the curriculum of the general upper secondary school aims to increase the self-responsibility and activity of young people.

Teacher: This study counselling and student welfare work has become far too difficult under the new law. Earlier, we used to a have pretty well-functioning student welfare group. But these days, meetings always have to be organized by the individual student, and this makes the work much more complicated. It's perhaps the reason why you don't catch [the problems of every student]. I've felt bad about that. I can understand the idea behind the law, but in practice it's made life at school difficult. 
This manuscript will be published in Disablity \& Society.

Researcher: Have you felt that some young people have left without support because of the [new law]?

Teacher: Yes. Or it just raises the threshold. Because I think that it's difficult to intervene anyway, because we see the students so little at one time. Following an individual student is much more difficult.

(Teacher, general upper secondary school)

We have analysed the statement of the teacher who argued that, under the new law, student welfare faces new practical challenges, leading to situations in which it is sometimes easier to ignore the needs for support or to postpone problem solving. The purpose of the law reform was to protect students' rights, but at a practical level, the result may make it more difficult to provide support for the students who need it. As presented above, the structure of general upper secondary school is course based, which also makes it challenging to identify any needs for support because teachers do not see the students frequently. Moreover, classes are large, each teaching group generally consisting of more than 30 students. The teacher's argument above is in contrast to the self-responsibility discourse, according to which obtaining support requires students and their families to be pro-active.

According to our analysis, the job description and support offered by special education teachers in general upper secondary schools is mainly consultative, individual pedagogical support given outside the mainstream classes (see also Sinkkonen et al 2016.). Hence, special education is mostly a separate addition to the teaching offered by subject teachers, rather than part of it, even though on the basis of curricular objectives, it should be a fundamental part of a school's educational culture and pedagogical practices. Due to limited resources, support is also limited to consulting assistance, rather than providing general pedagogical support in classrooms. One practical example is that the special education teacher's office was located on the basement floor. For students, simply going there could place them in the position of 'a special student' (see Mietola 2014). We argue that the current statement-centred system, together with insufficient resources, strengthens separate, private support practices instead of developing pedagogical support as an organic part of upper secondary school's everyday life. 
This manuscript will be published in Disablity \& Society.

\section{Conclusions}

Our analysis was based on an ethnographic study in one Finnish general upper secondary school, and we focused on the data concerning educational support. In spite of the limited data available to us, our analysis raises many intriguing and critical aspects of this research field, which has very seldom been studied. On the one hand, our analysis highlighted the study culture of upper secondary school as strongly academic and divided into classes by separate subjects, in which collaborative teaching and diverse support practices are not part of the common school culture. On the other hand, it emphasized the need to strengthen, open and diversify support practices to benefit more students. The lack of support was raised as both an education policy issue of economic resources being directed towards special needs education, and an issue of daily pedagogical practices that tended to be used in the school. By the latter, we mean that the support was mainly organized by special education teachers who scheduled individual meetings with students, but collaboration between subject teachers and special education teachers was rare. Although a school's budget clearly defines and limits practices, it does not define everything: customary practices also matter.

The needs for support and support practices were discussed in various ways, but we identified three intersecting discourses to which the arguments were mainly attached. As a result of our analysis, the right and privilege discourse worked as the basis for educational support organized in general upper secondary schools. Testing students and writing evaluations of their skills and learning difficulties - work mostly done by special education teachers - was rationalized and framed by a student's right to receive support. This discourse was also used to explain why special education teachers do not teach academic subjects and accordingly cannot work as co-teachers, because students have the right to be taught by qualified subject teachers. Hence, support was mostly organized individually and privately. However, some of the teachers argued for more communal, collaborative support practices in order to enhance the quality of teaching. This argument was also attached to the right and privilege discourse, yet contradicted the previous argumentation in it claim that by bringing special education teachers and their work into mainstream classrooms, it is possible to support more students and diminish the label of 'needing support' .

Stigmatization and individual deficit discourse appeared and was utilized, on the one hand, to explain the necessity of organizing support individually and privately, but on the other hand to argue for the importance of mainstreaming support practices so that special education 
This manuscript will be published in Disablity \& Society.

would not be seen as stigmatizing. The students' viewpoints regarding seeking support differed: some considered support to be a customized service to which they were entitled and did not emphasize stigmatization. Others considered asking for support to be stigmatizing and, for this reason, argued for teachers to be pro-active in organizing support and to pay attention to diverse learners in their teaching practices. The third discourse, self-responsibility for obtaining support, was entangled with both the right and privilege and stigmatization and individual deficit discourses by being an umbrella discourse for the whole conversation. This third discourse was emphasized by both the curriculum and the teachers and students in the discussions. The arguments varied between those of the curriculum, which heavily stresses the importance of developing students' self-responsibility skills, and the critical arguments of teachers and students, raising the spectre of leaving behind those students who are not able to fight for their rights to have support. There were also differences between students in how eager they were to seek support on their own. This clearly reflects students' earlier experiences of receiving special support during basic education and their experiences of stigmatization.

We were also interested in what kinds of meanings give support and the need for support, both in the discussions with the teachers and students and the school's everyday practices. We propose that the meanings of support are formulated and shaped when the decisions concerning job descriptions, individual tasks and resources allotted to special education teachers' work are made. These alignments define the meanings of support, whether this is understood as a separate addition to general teaching or as an organic part of the school's pedagogical practices. Moreover, the meanings of support are also shaped by the Matriculation Examination board, which makes it the special education teachers' responsibility to test students and write evaluative statements. Support thus obtains its meaning primarily as a bureaucratic action. Our analysis suggests that providing adequate resources for educational support, which means that every school has at least one full-time special education teacher, would provide more possibilities to implement multiprofessionality. A special education teacher could then sustainably participate in planning the courses with subject teachers and share their own knowledge with other teachers. The current resources shape support as an individual and separate addition to general teaching, even though, according to educational policy aims, support should be communal and collaborative. 
This manuscript will be published in Disablity \& Society.

The support given by special education teachers seemed to be useful to the students, and it was implemented as teaching and practising various learning and study skills, but also as encouragement and mental support during the meetings. On the other hand, the need for support also had stigmatizing meanings: to confess to one's personal difficulties and request help was seen as burdening the teacher and stigmatizing oneself as 'a slow learner' (see Niemi \& Mietola 2017; Youdell 2006). This relates to the wider culture of general upper secondary education, which prepares students for academic studies and an academic culture, usually emphasizing excellence in many ways. Yet support is neither seen as familiar nor is it wanted as part of an academic study culture. As a result of our analysis, we argue that diverse pedagogical practices should be recognized and acknowledged as part of a general upper secondary school's common practices. At the educational level, this has recently been realized by aligning special education and support practices in the legislation on general upper secondary schools. The resources directed towards educational support should now be increased in order to make special education teachers' work an organic part of schools' pedagogical space. In such a way, these communal, collaborative support practices, which are already aligned in the curriculum, could be better implemented. This in turn would enhance diverse students' possibilities to enter general upper secondary school and do well in their studies and, later on, facilitate their entry into higher education and working life. In addition, by reforming support and making it a visible and shared practice in a schools' everyday life, the negative and stigmatizing meanings it still sometimes evokes would be reduced.

\section{References}

Allan, Julie. 1999. Actively seeking inclusion. Pupils with special needs in special schools. London: Taylor \& Francis.

Arnesen, Anne-Lise, Mietola, Reetta \& Lahelma, Elina. 2007. Language of inclusion and diversity: policy discourses and social practices in Finnish and Norwegian schools. International journal of inclusive education, 11 (1), 97-110. DOI: 10.1080/13603110600601034

Ashby, Christine. 2010. The trouble with normal: the struggle for meaningful access for middle school students with developmental disability labels. Disability \& Society, 25 (3), 345-358. DOI: 10.1080/09687599.2018.1497949

Bacchi, Carol. 2000. Policy as Discourse: what does it mean? where does it get us? Discourse: studies in the cultural politics of education, 21(1), 45-57. doi:10.1080/01596300050005493

Benjamin, Shereen. 2002. The Micropolitics of Inclusive Education. An Ethnography. St 
This manuscript will be published in Disablity \& Society.

Edmundsbury Press Limited: Suffolk.

Done, Elizabeth J. \& Andrews, Mandy J. 2018. How inclusion became exclusion: policy, teachers and inclusive education. Journal of Education Policy,

https://doi.org/10.1080/02680939.2018.1552763

Eurydike. 2018. National education systems. Accessed October 302018. https://eacea.ec.europa.eu/national-policies/eurydice/national-description_en

Florian, Lani, Hollenweger, Judith, Simeonsson, Rune J., Wedell, Klaus, Riddell, Sheila, Terzi, Lorella, Holland, Anthony. 2006. Cross-cultural Perspectives on the Classification of Children with Disabilities: Part I. Issues in the Classification of Children with Disabilities. The Journal of Special Education 40 (1), 36-45. doi:10.1177/00224669060400010401

FNAE. 2015. Finnish National Agency for Education: National core curriculum for general upper secondary schools.

General Upper Secondary Schools Act (629/1998). Given in Helsinki 21.08.1998. Accessed October 302018.

https://www.finlex.fi/fi/laki/alkup/1998/19980629?search\%5Btype\%5D=pika\&search\% 5Bpika\%5D=lukiolaki

Goodley, Dan. 2014. Dis/ability studies. Theorising disablism and ableism. London: Routledge.

Grue, Jan. 2011. Discourse analysis and disability: Some topics and issues. Discourse \& Society 22 (5), 532-546. doi:10.1177/0957926511405572

Haltia, Nina., Jauhianen, Annukka., \& Isopahkala-Bouret, Ulpukka. 2017. Ei ylioppilastaustaiset korkeakouluopiskelijat [Nonupper secondary school graduates in higher education]. Helsinki: Opetus- ja kulttuuriministeriö.

Jauhiainen, Arto \& Kivirauma, Joel. 1997. Disabling school? Professionalisation of special education and student welfare in the Finnish compulsory school. Disability \& Society 12 (4), 623-641. doi:10.1080/09687599727164

Kauppila, Aarno, Kinnari, Heikki \& Niemi, Anna-Maija. 2018. Governmentality of disability in the context of lifelong learning in European Union policy, Critical Studies in Education, DOI: $10.1080 / 17508487.2018 .1533876$

Kirjavainen, Tanja, Pulkkinen, Jonna, \& Jahnukainen, Markku. 2016. Special education students in transition to further education: A four-year register-based follow-up study in Finland. Learning and Individual Differences, 45, 33-42.

Koski, Leena. 2011. Teksteistä teemoiksi - dialoginen tematisointi. In a book A. Puusa \& P. Juuti (eds) Menetelmäviidakon raivaajat. Perusteita laadullisen tutkimustavan valintaan. Vantaa: Hansaprint Oy, 126-149. 
This manuscript will be published in Disablity \& Society.

Kosunen, Sonja. 2016. Families and the social space of school choice in urban Finland. Helsinki: University of Helsinki.

Lahelma, Elina, Lappalainen, Sirpa, Mietola, Reetta \& Palmu, Tarja. 2014. Discussions That 'Tickle Our Brains': Constructing Interpretations through Multiple Ethnographic Data-sets. Ethnography \& Education 9 (1), 51-65. doi:10.1080/17457823.2013.828476

Lahelma, Elina \& Gordon, Tuula. 2007. Taustoja, lähtökohtia ja avauksia kouluetnografiaan. Teoksessa Lappalainen S. et al (eds,) Etnografia metodologiana. Lähtökohtana koulutuksen tutkimus. Vastapaino: Tampere, 17-38.

Lalvani, Priya. 2013. Privilege, Compromise, or Social Justice: Teachers' Conceptualizations of Inclusive Education. Disability \& Society 28 (1), 14-27.

doi:10.1080/09687599.2012.692028

Eli Langørgen \& Eva Magnus. 2018. 'We are just ordinary people working hard to reach our goals!' Disabled students' participation in Norwegian higher education, Disability \& Society, 33:4, 598-617. doi:10.1080/09687599.2018.1436041

Liasidou, Anastasia. 2012. Inclusive education and critical pedagogy at the intersections of disability, race, gender and class. Journal for Critical Education Policy Studies 10 (1), 168184.

Marcus, George. 1995. Ethnography in/of the World System. The Emergence of Multi-sited Ethnography. Annual Review of Anthropology 24, 95-117.

Mietola, Reetta. 2014. Troubling Special. An ethnographic study on practices of special education and formation of special in the everyday life of lower secondary school [Hankala erityisyys. Etnografinen tutkimus erityisopetuksen käytännöistä ja erityisyyden muotoutumisesta yläkoulun arjessa.] University of Helsinki: Studies in Educational Sciences.

MINEDU. 2018. General Upper Secondary Education. Accessed October 302018. https://minedu.fi/en/general-upper-secondary-education

Mehtäläinen, Jouko. 2005. The need for special education in upper secondary schools. [Erityisopetuksen tarve lukiokoulutuksessa.] Publications of the Finnish Education Evaluation Council 11. University of Jyväskylä: Jyväskylä. 
This manuscript will be published in Disablity \& Society.

Niemi, Anna-Maija. 2015. Erityisiä koulutuspolkuja? Tutkimus erityisopetuksen käytännöistä peruskoulun jälkeen [Special educational paths? A study on the practices of special needs education after basic education]. University of Helsinki, Institute of Behavioural Sciences, Studies in Educational Sciences 264.

Niemi, Anna-Maija \& Jahnukainen, Markku. 2018. Tuen tarve, työelämäpainotteisuus ja itsenäisyyden vaatimus ammatillisen koulutuksen kontekstissa [The need of support, working-life emphasis and self-responsibility in the context of vocational education and training]. Ammattikasvatuksen aikakauskirja, 20 (1), 9-25.

Niemi, Anna-Maija \& Mietola, Reetta. 2017. Between hopes and possibilities. (Special) educational paths, agency and subjectivities. Scandinavian journal of disability research, 19 (3), 218-229.

Niemi, Anna-Maija \& Kurki, Tuuli. 2014. Getting on the Right Track? Educational Choicemaking of Students with Special Educational Needs in Pre-vocational Education and Training. Disability \& Society 29 (10), 1631-1644. doi: 10.1080/09687599.2014.96618

Nylund, Mattias., Rosvall, Per-Åke., Eiríksdóttir, Elsa., Holm, Ann-Sofie., IsopahkalaBouret, Ulpukka., Niemi, Anna-Maija., \& Ragnarsdóttir, Guðrún. 2018. The academicvocational divide in three Nordic countries: implications for social class and gender. Education Inquiry, 9 (1), 97-121. doi:10.1080/20004508.2018.1424490

OSF. 2018. Official Statistics of Finland. Entrance to education [e-publication]. ISSN=1799-4527. 2016. Helsinki: Statistics Finland [referred: 26.9.2018].

OSF. 2018b. Special education, Helsinki: Statistics Finland, http://www.stat.fi/til/erop/index_en.html [accessed 2 April 2019].

Powell, Justin J. W. 2010. Change in Disability Classification: Redrawing Categorical Boundaries in Special Education in the United States and Germany, 1920-2005. Comparative Sociology 9, 241-267. doi:10.1163/156913210X12536181351079

Renold, Emma, Holland, Sally, Ross, Nicola J. \& Hillman Alexandra .2008. 'Becoming participant'. Problematizing 'informed consent' in participatory research with young people in care. Qualitative social work, 7 (4), 427-447. doi:10.1177/1473325008097139

Sinkkonen, Hanna-Maija, Kyttälä, Minna, Kiiskinen, Sanni \& Jäntti, Saara. 2016. Lukion erityisopettaja: opettaja, ohjaaja ja konsultti? [General upper secondary school's special education teacher: teacher, coach and consultant?] Oppimisen ja oppimisvaikeuksien erityislehti, 26 (3).

Skeggs, Beverley. 1995. Women's studies in Britain in the 1990s: entitlement cultures and institutional constraints. In Women's Studies International Forum (Vol. 18, No. 4, pp. 475485). Pergamon.

Slee, Roger. 2014. Discourses of Inclusion and Exclusion: drawing wider margins. Power and education 6 (1), 7-17. doi:10.2304/power.2014.6.1.7 
This manuscript will be published in Disablity \& Society.

Tomlinson, Sally .2008. Education in a post-welfare society. Second edition. Berkshire: Open University Press.

Troman, Geoff, Jeffrey, Bob \& Beach, Dennis. 2006. Researching Education Policy. Ethnographic Experiences. London: The Tufnell Press.

Unesco. 1994. The Salamanca Statement and framework for action on special needs education.

Youdell, Deborah .2006. Impossible bodies, impossible selves: exclusions and student subjectivities. Netherlands: Springer.

Law of Vocational education. 531/2017. 